\title{
Idolatria e canibalismo em relatos de missionários capuchinhos no Brasil e no Congo do século XVII ${ }^{1}$
}

\author{
Idolatry and cannibalism in missionary capuchins accounts in Brazil \\ and Congo of the XVII century
}

La idolatría y el canibalismo en informes de misioneros capuchinos en Brasil y Congo durante el siglo XVII

JoséRivairMacedo ${ }^{*}$

\section{Resumo}

Este artigo examina as representações acerca dos ameríndios Tupinambás e dos centro-africanos denominados jagas em relatos de missionários capuchinhos do século XVII, que atuaram no Brasil e no antigo reino do Congo. O texto desenvolve uma análise do retrato desses povos e do significado atribuído à idolatria e ao canibalismo na Histoire de la mission des pères capucins en l'Isle de Maragnan et terres circonvoisines (1614), de Claude d'Abbeville, e na Descrição histórica dos três reinos do Congo, Matamba e Angola (1687), de João Antônio Cavazzi de Montecuccolo.

Palavras-chave: Relatos missionários. Tupinambás. Reino do Congo.
Nas últimas décadas, tem crescido o número de trabalhos dedicados ao estudo dos contatos estabelecidos pelo Atlântico. As conexões entre a experiência histórica brasileira e a africana são exploradas em temas relacionados à escravidão e ao tráfico internacional que promoveram a diáspora dos africanos para a América. $\mathrm{O}$ foco de análise, deste artigo, dirige-se aos intercâmbios culturais e religiosos, às mútuas interferências e aos reflexos na cultura material - que dizem respeito, por exemplo, a trocas alimentares e a trocas técnicas - e, ainda, às interferências político-sociais recíprocas.

Neste trabalho, pretendemos perseguir a senda aberta por tais perspectivas re-

\footnotetext{
Professor do PPGH-UFRGS. Doutor em História. E-mail: jrivair@uol.com.br.
}

Recebido em 17/11/2014 - Aprovado em 25/03/2015 http://dx.doi.org/10.5335/hdtv.15n.1.5286 
lacionais de análise. A intenção não é buscar estabelecer conexões ou elementos de semelhança ou de continuidade entre as duas margens do Atlântico, mas tentar detectar a forma pela qual, em diferentes espaços explorados pelos portugueses, no Brasil e na África central, a proposta evangelizadora cristã de matriz europeia foi experimentada e confrontada com dois grupos caracterizados como praticantes da idolatria e do canibalismo: os tupinambás do Maranhão e os jagas do Congo e do Ndongo. Trata-se de tentar observar como o modelo cristão reagiu aos costumes de duas sociedades espacial e culturalmente diferentes, mas que se aproximavam ao integrar em sua cosmovisão elementos considerados estranhos e inconciliáveis com o modelo euro-cristão que se procurava nelas implantar.

\section{Capuchinhos}

Está por ser escrita uma obra de síntese que dê conta do papel dos franciscanos na formação do Brasil. Confirma-se, aqui, a afirmação reiteradamente repetida da desproporção entre o conhecimento e reconhecimento da obra jesuítica em detrimento da obra franciscana, e sua consequência maior, o relativo esquecimento do lugar dos frades menores na vida religiosa colonial e, inclusive, na ação evangelizadora durante aquele período ${ }^{2}$.

Não obstante, os franciscanos participaram ativamente em Portugal da obra missionária desde os primórdios das navegações, aspecto realçado há muito tempo por Jaime Cortesão. Eles acompanharam os navegadores lusos aos arquipélagos atlânti- cos da Madeira, dos Açores e Cabo Verde, à Guiné e ao Congo. A primeira missa no Brasil foi rezada por frei Henrique de Coimbra, o mesmo que pouco tempo depois daria início ao trabalho catequético nas Índias Orientais (CORTESÃO, 1990, p. 113). De outro modo, está bem estabelecido o protagonismo dos franciscanos na Nova Espanha, registrado nas obras dos frades Bernardino de Sahagun e Jeronimo de Mendieta (FERNANDES, 2007).

No Brasil, data da primeira metade dos quinhentos a presença de missionários franciscanos no litoral, embora o primeiro grupo enviado oficialmente pela Coroa Portuguesa tenha, ali desembarcado, em 1583. Antes disso, entre 1538-1548, um grupo liderado por frei Bernardo de Armenta permaneceu em Laguna, no litoral do atual estado de Santa Catarina, iniciando a conversão dos índios Carijós, deslocando-se, em seguida, para o Paraguai junto com o explorador Alvar $\mathrm{Nu}$ nez Cabeza de Vaca (COSTA, 2011). Além disso, deve-se aos franciscanos a autoria de obras imprescindíveis para o conhecimento da gente e da terra em processo de incorporação, de forma que informações de grande valor provêm da pena de escritores como Francisco do Rosário e frei Vicente do Salvador, no domínio luso, ou André Thévet, Yves d'Evreux e Claude d'Abbeville, provenientes de conventos franceses (DAHER, 2007).

No século XVII, aos frades franciscanos capuchinhos estaria reservado papel de destaque na obra missionária prevista nas orientações emanadas do Concílio de Trento, por meio da congregação romana denominada Sagrada Congregação da Propaganda Fide, fundada em 1622 sob o pontificado de 
Gregório XV. Para além da atividade pastoral e assistencial com as camadas populares dos reinos europeus, a catequização em terras de além-Mar era vista como prioritária pelos membros das ordens religiosas, missão reservada, aliás, aos mais aptos e melhor preparados (DOMPNIER, 1984; GUÉGNEN, 1960). Em Portugal, merece destaque a obra missionária de frei Cristovão de Lisboa, que liderou os frades capuchinhos na interação com os indígenas do Maranhão e Grão-Pará, em 1624-1635, dando continuidade ao trabalho iniciado por quatro frades na região amazônica desde 1617. Tratava-se, nesse caso, de ocupar um espaço nas comunidades nativas e eliminar a concorrência de missionários provenientes da França e da Holanda na América, África e Ásia (MARQUES, 1997). ${ }^{3}$

A experiência missionária dos franciscanos data dos primórdios da fundação da ordem, pois já em meados do século XIII não foram poucos os irmãos menores de Assis que se embrenharam nas rotas de ligação com o Mediterrâneo, o Oriente Médio e a Ásia central, em busca da conversão dos "infiéis" ou dos "pagãos". Notável, nesse primeiro momento, foi seu esforço de conversão dos povos politeístas turco-mongóis, e mesmo seu intento de fortalecer a posição do cristianismo latino na China, em face tanto de islâmicos quanto de budistas e cristãos nestorianos (DAINELLI, 1960; SILVEIRA, 2005).

De que maneira os costumes de povos vistos como pagãos foram concebidos, avaliados e enquadrados no discurso dos frades que se defrontaram com as realidades do Novo Mundo e da inóspita África no século XVII? Essa é a questão central que orienta a reflexão do presente estudo.
Os discursos dos frades capuchinhos, aqui considerados, foram enunciados em relatos que retratam duas experiências missionárias. A primeira ocorreu durante a efêmera tentativa de colonização francesa, resultante da expedição chefiada por Daniel de La Touche, senhor de La Ravardière, e por François de Rasilly, senhor de Aumelles, no Maranhão, entre 1612 e $1615 .{ }^{4}$ Da expedição e da empresa colonizadora conhecida como França Equinocial, tomaram parte quatro frades do convento dos capuchinhos de Paris, que atenderam prontamente ao pedido da rainha regente Maria de Médicis: Yves d'Evreux, Arsène de Paris, Ambroise d'Amiens e Claude d'Abbeville, autor do tratado intitulado Histoire de la mission des pères capucins en l'Isle de Maragnan et terres circonvoisines ou est traicté des singularitez admirables $\mathcal{E}$ des moeurs merveilleuses des indiens habitants de ce pais, publicada em Paris em 1614, que será examinado adiante. A permanência do autor em terras brasileiras foi de aproximadamente quatro meses, no segundo semestre de 1612, e as informações de que se serviu para compor o relato foram obtidas, em sua maior parte, de intérpretes que já conviviam há mais tempo com os indígenas tupinambás.

A obra de Claude d'Abbeville costuma ser considerada, junto com a de Jean de Lèry, André Thévet e Yves d'Evreux, um testemunho de primeiro plano da visão francesa dos indígenas e do Novo Mundo, que tanta repercussão teria no imaginário europeu e na caracterização da imagem do "bom selvagem". A perspectiva francesa sobre os indígenas e a América veio a ser tratada numa tese de doutorado defendida em 
2002, por Andrea Daher, e publicada no Brasil alguns anos depois (2007), cuja intenção reside mais na enunciação do discurso europeu do que sobre o que tal discurso poderia ter significado para a sociedade tupinambá - conforme apontam leituras críticas de sua obra (MAESTRI, 2008; HARRIGAN, 2004; BIDEAUX, 2003).

A segunda experiência missionária ocorreu na África centro-ocidental, entre 1645-1665, quando diversos frades capuchinhos, atendendo às demandas da congregação da Propaganda Fide, participaram dos esforços empreendidos por diversas missões católicas ${ }^{5}$ para a conversão dos povos dos reinos do Congo e de Ndongo. Cerca de 150 frades participaram da ação evangelizadora, atendendo diretamente aos ditames do papado, independente do projeto colonizador luso, o que por um lado conferiu certa originalidade ao empreendimento, e por outro acentuou suas divergências com os jesuítas. Os capuchinhos eram contrários ao tráfico negreiro, razão pela qual disputavam influência com os jesuítas, a quem denunciavam não apenas pelo apoio prestado ao tráfico, mas inclusive por possuir escravos (ALENCASTRO, 2000, p. 277-278).

O relato sobre o qual apoiaremos nossa análise é considerado o mais célebre registro dos primórdios da evangelização da África. Trata-se do texto intitulado Istorica descrizione de' tre regni, Congo, Matamba et Angola, de autoria de João Antônio Cavazzi de Montecuccolo (1621-1678), obra extensa, proveniente da experiência pessoal do escritor durante os treze anos que permaneceu no Congo e Ndongo (1654-1667). Indo além do relato pessoal, após o retorno à Europa, Cavazzi de Monteccúcolo colheu depoimentos de missionários, consultou cartas de religiosos, autoridades congolesas e portuguesas, além de ter obtido informações complementares registradas em crônicas anteriores que ele teve a oportunidade de consultar. O que se tem, portanto, é parcialmente o olhar de um narrador-participante e a obra de um erudito e pesquisador. $\mathrm{O}$ livro foi editado em Bolonha no ano de 1687 e, depois, traduzido para várias línguas (CAVAZZI DE MONTECUCCOLO, 1965).

O que a Istorica descrizione de tre regni e a Histoire de la mission des pères capucins en l'Isle de Maragnan tem em comum é o fato de que, nos diferentes territórios e ambientes culturais a que fazem referência, um mesmo problema se apresentava aos missionários: a "idolatria" dos nativos ameríndios ou africanos. Uma mesma expressão de recusa aos princípios do cristianismo aparecia num dos elementos que integravam o sistema de valores das populações idólatras: a prática da antropofagia.

\section{Tupinambás}

De modo geral, Claude d'Abbeville descreve a experiência do contato com os tupinambás em termos positivos, amistosos, tratando os índios com certa condescendência. Essa atitude missionária, designada por Andrea Daher como "predicação gentil", expressa uma estratégia de relacionamento adotada pelos franceses que contrastava com o modelo de colonização portuguesa, marcada pela violência contra os índios: 
[...] mas o uso da gentileza como método evangélico induz traços originais na tática empregada pelos capuchinhos na conversão dos Tupinambá: a conversão gentil se expressa, antes de mais nada, por uma tomada de consciência dos futuros conversos que constitui a própria essência da instrução visada pelos missionários (DAHER, 2004, p. 89).

Era como se os índios fossem seres ingênuos, desgarrados da civilização, mas propensos a ela. Numa passagem sintomática, desse ponto de vista, o escritor francês dá voz a Japiaçu, o mais destacado chefe indígena da região, e as palavras que esse, supostamente, dirigiu aos mair ${ }^{6}$, os franceses, resumem a pretensa posição dos indígenas em relação aos não indígenas. Segundo Japiaçu, os índios estariam predispostos a abraçar o cristianismo, pois esse teria sido, antecipadamente, anunciado em suas próprias crenças e costumes. Ele menciona a aparição dos profetas de Deus, que teriam, no passado, apresentado ao ancestral dos índios duas espadas, uma de madeira e outra de ferro, para que escolhesse a que mais desejasse:

Ele achou que a espada de ferro era pesada demais e preferiu a de pau. Diante disso o pai de quem sois descendentes, mais arguto, tomou a de ferro. Desde então, fomos miseráveis, pois os profetas, vendo que os de nossa nação não queriam acreditar neles, subiram para o Céu, deixando as marcas dos seus pés cravadas com cruzes no rochedo próximo de Potiú...

Depois disso surgiu entre nós a diversidade das línguas, pois antes tínhamos a mesma. De modo que não nos entendemos mais, massacramo-nos e comemos uns aos outros, fazendo o jogo do Jurupari. Depois de tantas misérias, para cúmulo de nossa infelicidade, essa maldita raça dos peró ${ }^{7}$ veio tomar nossa terra, esgotando essa grande e antiga nação e reduzindo-a a pequeno número... (D'ABBEVILLE, 1945, p. 61).
Os termos pelos quais é apresentada a condição de vida dos indígenas (infelizes, miseráveis) revelariam sua fragilidade e predisposição para a elevação espiritual por meio da conversão pelo batismo cristão. Os franceses, apresentados como amigos, seriam diferentes dos portugueses, tratados como "invasores" e "violentos". ${ }^{8}$ As antigas tradições, do tempo da idolatria, são descritas com reprovação e explicadas a partir da habitual polaridade deus/diabo - utilizada desde os textos medievais como recurso retórico na literatura dos exempla, como sublinhou com muita propriedade a pesquisadora Carmen Lícia Palazzo (2002). ${ }^{9}$

Alguns dos elementos apontados na citação anterior não constituem novidade no discurso dos missionários e na prática da evangelização, desde o relato dos primeiros franciscanos que cruzaram as estepes euro-asiáticas para converter muçulmanos, turco-mongóis, indianos e chineses. A estratégia para a conversão repete sempre o mesmo padrão: descaracterização das crenças que se pretende substituir e dos xamãs, pajés ou sacerdotes adversários; aprendizado da língua nativa e fixação por escrito dela em caracteres latinos; educação religiosa de crianças e mulheres - que se tornam difusoras da nova religião, até chegar aos homens e aos chefes; demonstração da anterioridade e superioridade do cristianismo (JACKSON, 2001).

A alusão aos profetas cristãos constitui um tópos do discurso missionário. Encontra-se disperso nos textos desde os tempos medievais, e muitos foram os evangelizadores que desejaram seguir os passos de São Tomé, o apóstolo das Índias (ETCHEBÉHÈRE JÚNIOR, 2005, p. 330) que, no Novo Mundo, 
passou a ser considerado o apóstolo dos índios. Sérgio Buarque de Holanda demonstrou, com sua notável erudição, a maneira pela qual a imagem de São Tomé e a alusão à sua passagem entre os índios americanos do litoral brasileiro, da região do Prata, do Paraguai e do Peru, resultou da fusão com a imagem do ancestral mítico tupinambá conhecido como Sumé, de onde, por vezes, a menção nas crônicas coloniais a São Sumé (HOLANDA, 1969, p. 104-125). As alusões ao motivo da impressão de pés humanos atribuída ao santo aparecem nas obras dos jesuítas Manuel da Nóbrega e Simão de Vasconcelos, e dos franciscanos Bernardo de Armenta e Frei Jaboatão, entre outros (CAVALCANTE, 2008).

Pode-se, então, perceber que nas entrelinhas do texto de Claude d'Abbeville estão vestígios das crenças indígenas, travestidas numa roupagem cristã, e não decodificadas pelo missionário. Essa hipótese pode ser demonstrada no episódio relativo ao ancestral dos tupinambá, designado nas palavras de Japiaçu como "nosso pai, do qual descendemos", e no tema da escolha entre a espada de madeira ou a de ferro. No século XX, os antropólogos recolheram da tradição oral dos índios Canela, Kraô e Timbira, o mito alusivo a um personagem conhecido como Aukê. Nascido numa aldeia indígena, mas demonstrando, desde o ventre materno, qualidades excepcionais, o menino que falava ao nascer e que se metamorfoseava em velho, ou no que quisesse, era tido como uma ameaça para o grupo - que tentou matá-lo de diversas maneiras sem obter sucesso -, até se transformar no primeiro homem branco. Procurado tempos depois pelo avô, Aukê lhe ofereceu a escolha entre a espingarda e o arco, mas, temendo a arma de fogo, o velho escolheu a outra arma, e os índios continuaram a ser como eram (MELATTI, 2007, p. 39).

Mas nem tudo era tranquilo nas relações entre franceses e indígenas, e pode-se pensar que a aparente disposição para a conversão decorresse em parte da expectativa natural do missionário, e em parte da superficialidade do contato, devido ao pouco tempo de existência concreta da França Equinocial. Já nesse pouco tempo pode-se, entretanto, entrever que alguns traços dos comportamentos indígenas, justamente aqueles mais enraizados em sua cultura, causavam desagrado. Tais comportamentos estavam associados aos usos corporais (pinturas, adornos, incisões e perfurações) e outros a ritos sociais (bebedeira coletiva, conhecida como cauinagem; saudação lacrimosa ${ }^{10}$, ritos fúnebres). ${ }^{11}$

O que se pode depreender é que, embora aparentemente predispostos a aceitar os cristãos e o cristianismo, os índios mantinham suas tradições, algumas das quais afrontavam os princípios que se pretendia neles incutir. É o que Claude d'Abbeville diz ter acontecido após a morte de um menino que fora enviado a um pajé, "para que o soprasse e o curasse". As demonstrações de dor pela perda da criança se manifestavam na forma de choros, gritos lancinantes e lamentos pungentes tão fortes que se ouvia em toda a aldeia, e o missionário confessa: “[...] vendo que não punham fim a suas lamentações, fomos obrigados a procurar um lugar distante, do outro lado da aldeia, para passarmos o resto da noite" (D'ABBEVILLE, 1945, p. 97). 
Mas, o costume tido como mais execrável, aquele que na opinião do missionário reduzia os tupinambás à condição de selvageria, era mesmo o canibalismo, prática descrita na citação aqui examinada, como fruto da ignorância e da incompreensão entre as nações indígenas, que se massacravam e devoravam umas às outras. Como era de se esperar, a antropofagia é considerada a partir de um ponto de vista moral, o que lhe confere posição bem diferente daquela tida no sistema de valores dos indígenas.

Para Claude d'Abbeville, a prática do canibalismo era indicativo de selvageria porque ia contra o instinto de preservação da espécie. Ao narrar o assassinato de uma índia escrava de Japiaçu, diz que devido aos efeitos do cauim $^{12}$ o chefe mandou matá-la, e os demais presentes, entre os quais algumas índias velhas, esquartejaram o corpo e a devoraram, sendo inclusive enviados pedaços a uma aldeia vizinha (p. 133). Isso motivou a condenação do chefe indígena, que teve de se retratar sob pena de punição severa, a qual seria aplicada pelos franceses. O que importa sublinhar é que tais informações destoam daquelas apresentadas nos relatos quinhentistas de autores como Hans Staden, Jean de Léry e Gabriel Soares de Souza, em que o canibalismo é descrito a partir de seus elementos rituais, associado ao sistema de vingança e às relações de guerra entre as nações indígenas. De acordo com esses autores, não era qualquer indivíduo o escolhido para o sacrifício, mas os inimigos..$^{13}$

Não escapava a Claude d'Abbeville a dimensão ritual e simbólica do canibalismo. Em seu relato, ele descreve detalhadamente todas as etapas que envolviam aprisiona- mento, preparação e realização do sacrifício dos guerreiros adversários, em data previamente marcada, cercada de toda a cerimônia e diante de toda a aldeia, que sabia que a ingestão de carne tinha a implicação mágica da apropriação da força do sacrificado - o qual, depois de morto, era lançado ao fogo para queimarem-se os pelos, e a seguir lavado em água quente, esquartejado e assado. Mas insiste no aspecto macabro da cena, reforçando o caráter exótico do ritual:

Deitam fogo embaixo da grelha sobre a qual colocam todos os pedaços do pobre corpo estraçalhado: cabeça, tronco, braços e coxas, sem esquecer pernas, mãos, pés, inclusive entranhas ou parte delas, ficando o resto para o caldo. Nada perdem, em suma, e tem o cuidado de virar os pedaços para bem assá-los; e aproveitam até a gordura que escorre pelas varas e lambem a que se coagula nas forquilhas. Tudo bem assado e cozido, comem os bárbaros essa carne humana com incrível apetite. Os homens parecem esfomeados como lobos e as mulheres mais ainda. Quanto às velhas, se pudessem se embriagar de carne humana de bom grado o fariam (D'ABBEVILLE, 1945, p. 233).

\section{JAGAS}

O posicionamento dos membros da missão de capuchinhos italianos enviada ao Congo em relação aos costumes dos povos centro-africanos difere daquele dos capuchinhos franceses em relação aos ameríndios, embora os elementos socioculturais em referência tenham sido estruturalmente semelhantes. De modo geral, na descrição dos habitantes do Congo e do Ndongo, o frade Cavazzi de Montecuccolo mantém sempre um tom de crítica e de desconfiança diante 
das instituições e do modo de vida daqueles a quem lhe foi confiada a árdua tarefa da conversão. Não faltam em seu texto palavras ásperas de denúncia da poligamia, dos rituais e, sobretudo, da idolatria que persistia no culto aos espíritos ancestrais, beberragens e sacrifícios, tudo isso inspirado por sacerdotes e feiticeiros identificados pelos termos de nganga e ngonho. Também são denunciados juramentos com caráter de ordálio ${ }^{14}$, choro, danças, berros e "agitação decomposta", ocorridos nos funerais (CAVAZZI DE MONTECUCCOLO, 1965, p. 93, 105-107, 184, v. 1).

É muito provável que tal posicionamento esteja relacionado a dois fatores. Primeiro, embora a difusão do catolicismo no Congo remontasse ao início do século XVI, era perceptível o quanto sua implantação tinha sido superficial, o que se podia verificar na persistência de elementos rotulados negativamente como idolatria e superstição. De fato, muitas pesquisas sobre esse assunto comprovam que a adoção do cristianismo pelos congoleses não foi imediata, nem isenta de interesses de ambas as partes envolvidas no processo de conversão: a assimilação dos elementos cristãos por meio das línguas nativas criava fusões e associações entre o cristianismo e o universo mágico-religioso dos congoleses, "num jogo especular que tendia a preservar, sob verniz cristão, antigas práticas religiosas e culturais" (NSONDÉ, 1992, p. 708). Isso se deveu, em grande parte, à própria estratégia dos missionários que, para tornar inteligível a doutrina que tentavam transmitir, recorreram com frequência ao léxico local para expressar ideias cristãs, o que gerou fusões inesperadas e muitas ambiguidades, o que se depreende da análise do primeiro catecismo bilíngue escrito em português e kikongo, no ano de 1624 (MACEDO, 2013a).

O binômio cristianismo/civilização, também aqui, aparece contraposto ao binômio paganismo/selvageria, mas o escritor tem ciência da fina camada de verniz sobreposta aos traços sociais próprios dos congoleses. Cavazzi de Monteccúcolo nota, por exemplo, que a maior predisposição para a conversão encontrava-se entre as populações do litoral, das margens dos rios navegáveis, ou de cidades, propondo a seguinte explicação: "lidando com os portugueses ou com outros europeus, são iluminados pela luz da civilização e por noções mais humanas e mais razoáveis" (1965, p. 86, v. 1). As regiões mais afastadas, do interior, de acordo com o seu raciocínio, estariam mais "contagiadas", dominadas pelos antigos mestres e antigos costumes.

No período em que Cavazzi de Montecuccolo redigia sua obra, o reino do Congo encontrava-se parcialmente esvaziado de poder, especialmente após a derrota das tropas congolesas frente aos portugueses e seus aliados na batalha de Ambuíla (Mbwila), ocorrida em 1665, com a morte do manicongo Antônio I e a subsequente crise de sucessão e conflitos internos que culminaram com o saque e abandono temporário da cidade de São Salvador. A autoridade do manicongo passou a ser contestada e disputada por sobas que controlavam áreas periféricas (VANSINA, 1965, p. 51-53; THORTON, 1982, p. 337).

$\mathrm{Na}$ realidade, desde 1567 os povos denominados mbangalas, mais conhecidos como jagas, tinham invadido o Congo e alterado o instável equilíbrio então existente (PINTO, 1999-2000). Ao longo da primeira 
metade do século XVII, esses grupos de guerreiros atuaram sob a liderança de seus chefes em operações militares promovidas pelos governantes do Congo, Ndongo e pelos portugueses, naquilo que aparece descrito nos documentos como "guerra preta". Sua ferocidade nos combates, tenacidade e instituições sociais foram vistas com estranhamento e despertaram repulsa e pavor generalizado (MACEDO, 2013b). Eis os termos pelos quais eles são caracterizados na Istorica descrizione:

É uma gente de cuja boca sai continuamente a mentira e a falsidade, sempre dada ao roubo e a qualquer crime. É um povo sempre sedento de sangue e de carnificina, ávido devorador de carne humana, feroz contra as feras, cruel para com os inimigos e até contra os próprios filhos. Numa palavra: parece animado por sentimentos tão maus que o inferno nunca vomitou fúrias e tiranos que possam servir se comparação (CAVAZZI DE MONTECUCCOLO, 1965, p. 175, v. 1).

É inútil avaliar os costumes sociais dos jagas com base em olhar tão desfavorável como o que aqui se apresenta. Nele se entrelaçam juízos morais e um conjunto de princípios que rechaçam o estilo de vida da população retratada. De modo geral, pondo de lado os condicionamentos culturais que orientam os juízos do autor, o que se pode depreender objetivamente da longa descrição são os seguintes pontos: 1) a forma de organização social fundamental dos jagas era a tribo, mantida sob a autoridade de uma chefia - que podia ser ocupada por homens ou mulheres; 2 ) as atividades essenciais eram a caça, a coleta e a guerra, com os subsequentes saque e pilhagem; 3 ) as tradições que davam suporte ao exercício da guerra eram calcadas no politeísmo, com o culto aos espíritos dos ancestrais, rituais e sacrifícios propiciatórios.

$\mathrm{O}$ elemento cultural que mereceu maior destaque no texto de Cavazzi de Montecuccolo foi o canibalismo, visto como indício da selvageria extrema dos jagas. Eles se alimentariam de frutas, ervas, raízes e carne humana: "comiam até carniças fétidas e caçavam toda espécie de bichos". Os inimigos eram parcialmente retidos em cativeiro, ou então massacrados - sendo degolados, tendo as cabeças cortadas e expostas como troféus (CAVAZZI DE MONTECUCCOLO, 1965, p. 175-176, v. 1). Tal qual ocorre na descrição deixada por Claude d'Abbeville a respeito dos tupinambá, a antropofagia é reduzida ao aspecto puramente alimentar.

A despeito da intenção moralizadora do frade capuchinho, muitas informações permitem associar as práticas cruentas dos jagas com o tipo de sociedade belicosa de que participavam. A imputação do assassinato de crianças (CAVAZZI DE MONTECUCCOLO, 1965, p. 186, v. 1) parece ser a desfiguração de traços das tradições orais dos mbangalas pelo missionário, que tomou ao pé da letra elementos de seus mitos de origem. Conforme Joseph Miller demonstrou em análise minuciosa há várias décadas, a cerimônia de matar as crianças simbolizava o poder absoluto do governante das comunidades jagas, chamadas kilombo ${ }^{15}$, sobre os seus súditos, pois os "filhos", nas narrativas orais, representam os súditos de um chefe político, em contraste com os seus parentes, que são sempre descritos como "sobrinhos e sobrinhas". Num sentido mais literal, porém, a matança dos filhos, quando praticada por toda uma população, tornava- 
-se um meio de abolir as linhagens, uma vez que o assassinato dos filhos (ou a negação do significado social de um nascimento físico) tinha sobre os grupos de filiação o mesmo efeito estrutural que a proibição do seu nascimento (MILLER, 1995, p. 163).

Quanto ao canibalismo, as informações sugerem que estivesse integrado a um ritual específico, denominado sembamento, ${ }^{16}$ que comportava sacrifícios humanos realizados sob a liderança de sacerdotes locais (xinguila) (CAVAZZI DE MONTECUCCOLO, 1965, p. 186, v. 1). ${ }^{17}$ Nele, os adversários reduzidos em cativeiro eram eliminados coletivamente, por ocasião da ascensão ou morte de chefes ou dos jagas mais importantes da comunidade. Nesse momento, os prisioneiros eram coroados com grinaldas, recebiam cumprimentos e obséquios dos presentes, súplicas para que intercedessem pelos vivos, sendo posteriormente executados e devorados. A ingestão de carne humana parece ter sido compreendida como transferência de energia vital, o que explica que aos chefes estivesse reservado o direito de comer o coração dos inimigos principais (CAVAZZI DE MONTECUCCOLO, 1965, p. 184,195 , v. 1). Nos sistemas de valores dos povos de tradição cultural bantu, o universo é concebido como impregnado de energia cuja fluência e distribuição motivam os comportamentos, fundam as crenças religiosas, desenvolvem e justificam a magia e impregnam os atos sociais:

[...] para os africanos, a energia divina está presente em todas as partes da criação, de modo que os homens, as outras criaturas viventes e até os fenômenos naturais estão dela penetrados e acham-se, por isso, em comunhão (ALTUNA, 2006, p. 50).
A relação entre a prática do canibalismo e a crença na energia vital transparece na passagem a seguir, em que os juízos morais desfavoráveis não obscurecem a identificação do significado cultural provavelmente compartilhado pelos participantes do sacrifício:

Os jagas, para maior alívio da alma dos finados, depois de sacrificarem homens e animais, penduram os corpos das vítimas com a cabeça para baixo, sobre a campa, e cortando as cabeças, deixam que todo o sangue caia sobre a mesma. Por fim, cortam todos os outros membros para que qualquer resto de sangue seja também derramado. Durante esta supersticiosa cerimônia, porém, não cuidam da sede do falecido, mas também na sua própria, pois enchem de sangue algumas taças e bebem-no avidamente (CAVAZZI DE MONTECUCCOLO, 1965, p. 187, v. 1).

Da leitura dos dois relatos de missionários capuchinhos, há uma perceptível diferença de tom, que decorre, provavelmente, da maior frustração, ou não, do empreendimento missionário. $\mathrm{O}$ otimismo de Claude d'Abbeville em relação aos tupinambá do Maranhão diverge do pessimismo e da desconfiança de Cavazzi de Montecuccolo em relação aos jagas da área Congo. Não obstante a tarefa missionária ter sido a mesma, qual seja, a erradicação do paganismo daquelas sociedades. Essa diferença de tom tem a ver com o grau de envolvimento dos missionários e com o tempo do trabalho missionário em que estiveram envolvidos. Em ambos os casos, a expectativa de uma conversão rápida aos valores cristãos esbarrou numa tenaz e desconcertante continuidade das práticas de idolatria após a conversão ao cristianismo, algo que aqueles padres não conseguiam compreender - e muito menos aceitar. 
No relato de Claude d'Abbeville, já se pode identificar um princípio de manifestações de frustração, expresso de modo muito mais enfático pelos jesuítas em relação ao comportamento dos tupinambá, que se mantinham presos aos costumes pagãos por muito mais tempo do que era esperado. A adoção plena do cristianismo teria implicações muito profundas em seus modos de organização social e sistemas de valores, motivo pelo qual aquilo que parecia essencial ao tupinambá acabava não sendo alterado. Daí ter sido frequente no discurso missionário primeiro o tópos da predisposição inata à conversão dos indígenas, e depois os relatos sobre sua inconstância e abandono da nova crença (CASTRO, 2002). Desde os estudos pioneiros de Florestan Fernandes, admite-se que a guerra, a vingança e o sacrifício dos inimigos eram elementos estruturantes na sociedade guerreira tupinambá, estando profundamente enraizadas no sistema religioso tribal:

Em torno da obrigação dos vivos para com os mortos, da vingança dos antepassados e da satisfação dos desejos antropofágicos dos espíritos é que se polarizavam as vivências masculinas e os núcleos de condensação e de intensificação da vida social, especialmente dos homens (FUJIMOTO, 2008, p. 216).

De outro modo, embora o testemunho dos missionários capuchinhos acerca dos costumes dos ameríndios e centro-africanos deva ser submetido a mais severa crítica, de modo que sejam depurados das projeções imputações de estereótipos e juízos de caráter moral, ainda assim, as duas narrativas examinadas nos permitem avaliar indiretamente, numa relação especular, o provável impacto dos sistemas de valores dos nativos, a partir das reações do olhar cristão. Isso porque havia pontos de proximidade, ou pelo menos de contato, entre o universo mítico-religioso europeu, indo-americano e africano. Foi o que permitiu, aliás, que tupinambás e congoleses pudessem negociar culturalmente com um sistema de crenças que, em última instância, não era refratário aos elementos que fundamentavam e davam coerência aos códigos culturais específicos que orientavam sua forma de percepção do mundo.

Os três grupos, em última instância, admitiam, em suas respectivas cosmologias, a existência de entidades criadoras do universo: Deus, na tradição judaico-cristã, entidades criadoras ou preexistentes, nas tradições indígenas e africanas. Não quer dizer que o significado dessas entidades fosse correlato, mas apenas aproximado.

Os estudos de John Thorton e, sobretudo, de James Sweet, lançam luz sobre as razões pelas quais, não obstante as discrepâncias, os contatos dos missionários cristãos com os centro-africanos produzissem aproximações e intercâmbio entre seus respectivos sistemas de crenças. Ambos fundamentavam-se na ideia da revelação - expressa por meio do milagre cristão, dos vaticínios, das adivinhações, das incorporações ou das possessões dos sacerdotes ameríndios e africanos. Porém, enquanto no caso euro-cristão a incidência da revelação (milagre) era admitida como um fenômeno excepcional, como uma manifestação extremamente rara da vontade de Deus ou do poder de um santo, no caso dos africanos ela era frequente, contínua e incluía uma vasta gama de divindades locais e espíritos ancestrais. Assim, suas 
respectivas finalidades tornavam-nas crenças e cosmogonias diferentes, situação ainda mais agravada pela posição monopolista dos sacerdotes cristãos em face de seus congêneres africanos (THORTON, 2004, p. 312-321; THORTON, 2013; SWEET, 2007, p. 127-140).

Outros índices sugerem áreas de confluência de significado entre as práticas religiosas cristã, ameríndia e africana. As diferenças dependeram sempre do significado atribuído a elementos parcialmente recorrentes que alimentavam as respectivas tradições culturais. O papel do sacrifício e do sangue, por exemplo, mostra-se aspecto muito significativo tanto nas tradições do catolicismo cristão (ritual da eucaristia) (ROUX, 1988; CABIÉ, 1990) quanto nas tradições dos tupinambá - mesmo que no ritual antropofágico o sacrifício não apareça envolvido por um halo eminentemente religioso - e dos centro-africanos, em que o sacrifício humano tem ligações profundas com as práticas mágicas de transferência e aquisição de poder. Visto desse ângulo, o valor positivo ou negativo dependia exclusivamente do ponto de vista de quem detinha o monopólio da escrita, que, por sua vez, aparece submetida aos desígnios da conversão.

\section{Notas}

1 A primeira versão deste texto foi apresentada no VI Encontro Luso-Brasileiro de História Medieval, intitulado Raízes medievais do Brasil moderno, realizado nas dependências da Faculdade de Letras da Universidade de Coimbra, de 2 a 4 de novembro de 2011.

2 Gilberto Freyre argumentava que “[...] o que tem faltado no Brasil é método, sistema, organização no registro apologético dos seus feitos; de modo que a recordação de esforços, alguns heróicos, por eles ou por alguns deles desenvolvidos, está menos na história erudita do que no folclore" (1959, p. 15-16).

3 A ação de missionários franciscanos provenientes da Bretanha continuou, todavia, a ocorrer com autorização da Coroa Portuguesa ao longo de todo o século XVII, e entre 1642 e 1654 eles se estabeleceram em Pernambuco, de onde partiriam para a Paraíba e dariam início à conversão dos indígenas, em 1671 (GABRIELLI, 2009).

4 A expedição era composta por três navios, algumas centenas de colonos, dezenas de soldados, vintena de oficiais nobres ou de famílias abastadas e marinheiros, provenientes em geral da Bretanha. Na avaliação dos historiadores, a estratégia adotada para a colonização seguiu o mesmo padrão adotado pelos portugueses: em torno de um núcleo de povoamento europeu dedicado às atividades agrícolas, ao comércio e ao artesanato, foram tomadas iniciativas visando reagrupar povos indígenas, convertê-los ao cristianismo e transformá-los em aliados (JARNOUX, 1991).

5 A missão carmelita permaneceu entre 1584-1587; a jesuíta, entre 1619-1675; e a capuchinha, entre 1645-1845. Nota-se, além disso, que enquanto as missões das outras congregações religiosas foram incentivadas pela Coroa Portuguesa, os capuchinhos atendiam diretamente às autoridades romanas, o que não deixou de ter consequências no complexo jogo de alianças e influências nas terras africanas. Considere-se ainda a existência de capuchinhos espanhóis no Congo, caso de Mateo de Anguiano, Juan de Santiago e Antonio de Teruel, que atuaram no Ndongo, Benin, Guiné e Serra Leoa (RICARD, 1958; RANDLESS, 1968).

6 O nome usado pelos tupinambás para designar os franceses.

7 O nome usado pelos tupinambás para designar os portugueses.

8 As estratégias de conversão adotadas anteriormente pelos jesuítas, no século XVI, de fato reproduziam de modo mais enfático a ideologia da conquista colonial, e esbarravam em resistência tenaz dos indígenas (MAESTRI, 2013, p. 161-167).

9 O recurso ao exemplum na História da missão dos padres capuchinhos na Ilha do Maranhão e terras circunvizinhas tinha caráter eminentemente pedagógico. Conforme Palazzo, "as imagens fortes - fossem elas verbais ou iconográficas - faziam parte da bagagem dos missionários e eram especialmente adotadas pelos frades pregadores das ordens menores. A veemência das pregações franciscanas era conhecida desde a Idade Média e os capuchinhos, um ramo mais recente dessa ordem, também se destacaram ao usar imagens de grande apelo popular" (2002, p. 101). 
10 Trata-se de uma recepção cerimonial reservada aos estrangeiros, pela qual as mulheres costumavam chorar muito enquanto davam as boas vindas. Este traço de comportamento, considerado bizarro, chamou a atenção de cronistas e viajantes, entre eles Fernão Cardim, no Tratado da terra e gente do Brasil (1580), e André Thévet, na obra Singularitez de la France Antarctique (1556).

11 As fontes de informação sobre esses cultos, ritos e mitos são cronistas e relatos de viajantes do século XVI-XVII, que serviram de base para o estudo clássico de Alfred Métraux (1979, p. 299-308).

12 A bebida feita a partir do líquido resultante do milho fermentado.

13 O tema do canibalismo chamou a atenção dos cronistas devido ao seu caráter exótico e extraordinário, e parece muito difícil comprovar que tal prática era efetivamente realizada no período dos contatos com os colonizadores e conquistadores europeus. Será preciso distinguir a prática ritual daquilo que se pode como o "mito do canibalismo", como demonstram os pesquisadores germânicos Ulrich Fleishmann, Rodrigo e Zinka (1994, p. 36).

14 Entre esses estava o kilumbo, que consistia na aplicação de uma chapa de ferro bem quente, aplicada sobre a carne de um acusado que tivesse jurado inocência. Convém lembrar, todavia, que os ordálios por meio da prova do ferro quente integravam as tradições ancestrais indo-europeias, e que foram admitidos pelas autoridades até pelo menos o século XII, quando passaram a ser banidos dos procedimentos judiciais - sem, contudo, desaparecer nas manifestações populares (GRIPPARI, 1987).

15 Na África central do século XVII, este termo de origem kimbundo tinha duas acepções oscilantes e intercambiáveis. Em primeiro lugar, designava um arraial, um acampamento defensivo mais ou menos permanente, com finalidade militar. Em segundo lugar, designava a ideia de ajuntamento, de união entre certos indivíduos, amplamente difundida no Congo, Matamba, Ndongo, e nos estados ovimbundo do atual planalto central angolano, onde provavelmente teve a sua origem (PARREIRA, 1990, p. 153).

16 Nas antigas tradições mbundo, os termos samba ou semba, tamba ou temba, estavam relacionados aos principais títulos dos governantes do kilombo, sambanza para os maridos e tembanza para as esposas. A prática de canibalismo na ocasião da ascensão dos governantes mbangalas ocorreu de modo residual até pelo menos a segunda metade do século XIX. Nessas ocasiões, um indivíduo, denominado nicongo, era executado, real ou sim- bolicamente, e depois sua carne era cozida junto com a carne de animais e consumida num banquete coletivo entre o rei e os chefes de linhagens, chamados macotas (CARVALHO, 1898, p. 432).

17 Havia uma relação entre feitiçaria, escravidão e canibalismo entre os povos de língua kikongo e kimbundo, consubstanciada na ideia de que determinados feiticeiros ou determinados reis comiam o coração de suas vítimas para adquirir poder, aspecto transferido para o Novo Mundo através da figura do "branco canibal" - tema presente nos relatos orais dos cativos afro-americanos (THORTON, 2003). O costume também aparece na antiga tradição mbundo, em que, segundo Cadornega, encontrava-se difundida a crença de que chefes fundadores de linhagens comiam o coração dos velhos (CHILDS, 1960, p. 276).

\section{Abstract}

This article examines the representations about the indigenous american group of Tupinambás and the african group called jagas in the accounts of missionary capuchins of the seventeenth century in Brazil and ancient kingdom of Congo. The text explores the portrayal of these peoples and the significations of cannibalism and idolatry in the Histoire de la mission des pères capucins en l'Isle de Maragnan et terres circonvoisines (1614) de Claude D'Abbeville, and Istorica descrizione de' tre regni, Congo, Matamba et Angola (1687) de Giovanni Antonio Cavazzi de Montecuccolo.

Keywords: Missionary accounts. Tupinambás. Kingdom of Kongo.

\section{Resumen}

En este artículo se expone un análisis de las representaciones acerca de los índios tupinambás y de los centro-africanos denominados de Jagas en informes de 
misioneros capuchinos que actuaran en Brasil y en el antiguo reino del Congo durante el siglo XVII. El texto analiza la imagen de estos grupos y el significado dado a la idolatría y el canibalismo en la Histoire de la mission des pères capucins en l'Isle de Maragnan et terres circonvoisines (1614), de Claude d'Abbeville, y en la Istorica descrizione de' tre regni, Congo, Matamba et Angola (1687) de Giovanni Antonio Cavazzi de Montecuccolo.

Palabras clave: Informes misioneros. Tupinambás. Reino del Congo.

\section{Referências}

ALENCASTRO, Luiz Filipe de. O trato dos viventes: formação do Brasil no Atlântico Sul. São Paulo: Companhia das Letras, 2000.

ALTUNA, Pe. Raul Ruiz de Asúa. Cultura tradicional bantu. Luanda: Paulinas, 2006.

BIDEAUX, Michel. Les singularitez de la France équinoxiale. Bulletin de l'Association d'Étude sur l'Humanisme, la Reforme et la Renaissance, Paris, n. 57, p. 191-193. 2003.

CABIÉ, Robert. La communion des fidèles au sang du Christ. Pourquoi a-t-elle disparu en Occident et persisté en Orient?. Bulletin de Littérature Ecclésiastique, Toulouse, v. 91, p. 175188. 1990.

CARVALHO, Henrique Augusto Dias de. O jagado de Cassange - província de Angola. Lisboa: Cristovão Augusto Rodrigues, 1898.

CASTRO, Eduardo Viveiros de. O mármore e a murta: sobre a inconstância da alma selvagem. In: A inconstância da alma selvagem $e$ outros ensaios de antropologia. São Paulo: Cosac \& Naify, 2002. p. 181-264.
CAVALCANTE, Thiago Leandro Vieira. Apropriações e ressignificações do mito de São Tomé na América: a inclusão do índio na cosmologia cristã. 2008. Dissertação (Mestrado em História) - Programa de Pós-Graduação em História, Universidade Federal da Grande Dourados, Dourados, 2008.

CAVAZZI DE MONTECUCCOLO, João Antônio. Descrição histórica dos três reinos do Congo, Matamba e Angola. Trad. Graciano Maria de Leguzzano. Lisboa: Junta de Investigações do Ultramar, 1965. $2 \mathrm{v}$.

CHILDS, Gladwyn Murray. The peoples of Angola in the seventeenth century according to Cadornega. Journal of African History, v. 1, n. 2, p. 271-279. 1960.

CORTESÃO, Jaime. Os descobrimentos portugueses. Lisboa: Imprensa Nacional - Casa da Moeda, 1990.

COSTA, Sandro Roberto da. O protagonismo dos franciscanos na evangelização do Brasil antes dos jesuítas: a experiência de Laguna. Cinteotl: Revista de Investigación en Ciencias Sociales y Humanidades, Hidalgo, n. 13. 2011. p. 1-14.

D'ABBEVILLE, Claude. História da missão dos padres capuchinhos na Ilha do Maranhão e terras circunvizinhas. São Paulo: Livraria Martins, 1945.

DAHER, Andrea. A conversão dos tupinambá entre oralidade e escrita nos relatos franceses dos séculos XVI-XVII. Horizontes Antropológicos, Porto Alegre, a. 10, n. 22, p. 67-92, 2004.

. O Brasil francês: as singularidades da França equinocial: 1612-1615. Rio de Janeiro: Civilização Brasileira, 2007.

DAINELLI, Giotto. Missionari e mercadanti rivelatori dell'Asia nel Medioevo. Torino: Unione, 1960.

DOMPNIER, Bernard. Les missions des capucins et leur empreinte sur la reforme catholique en France. Revue d'histoire de l'Église de France, Paris, v. 70, n. 184, p. 127-147. 1984. 
ETCHEBÉHÈRE JÚNIOR, Lincoln. Cristandade Oriental: as relações entre a igreja nestoriana e os cristãos de São Tomé no período medieval. In: ENCONTRO INTERNACIONAL DE ESTUDOS MEDIEVAIS, 5. 2005, Salvador. Anais... Salvador: Quarteto, 2005. p. 326-332.

FERNANDES, Luiz Estevam de Oliveira. O franciscanismo espanhol em terras americanas: os irmãos menores na Nova Espanha do século XVI. Revista Aulas, Campinas, n. 4, p. 1-27, 2007.

FLEISHMANN, Ulrich; ROHRIG, Mathias; ZIEBEL-WENDT, Zinka. Os tupinambá: realidade e ficção nos relatos quinhentistas. Penélope: fazer e desfazer a História, Lisboa, n. 14, p. 23-41. 1994.

FREYRE, Gilberto. Em torno do esforço franciscano no Brasil. In: - A propósito de frades. Salvador: Universidade da Bahia, 1959. p. 14-26.

FUJIMOTO, Juliana. Guerra e antropofagia em Jean de Léry e Claude d'Abbeville: dos fragmentos míticos ao código compartilhado. Dissertação (Mestrado em História) - FFLCH, Universidade de São Paulo, São Paulo, 2008.

GABRIELLI, Cassiana Maria Mingotti. Capuchinhos bretões no Estado do Brasil: estratégias políticas e missionárias. Dissertação (Mestrado em História) - FFLCH, Universidade de São Paulo, São Paulo, 2009.

GRIPPARI, Marie-Noelle. Le jugement de Dieu ou la mise en jeu du pouvoir. Revue Historique, Paris, n. 564, p. 281-290. 1987.

GUÉGNEN, Édouard. Les pères capucins du Louvre en Bretagne au XVII siècle. Revue d'histoire de la Pharmacie, Paris, n. 164, p. 290292. 1960.

HARRIGAN, Michael. Les singularitez de la France equinoxiale. French Studies, Oxford, v.58, n. 1, p. 93-94. 2004.

HOLANDA, Sérgio Buarque de. Visão do paraíso: os motivos edênicos da colonização bra- sileira. São Paulo: Companhia Editora Nacional/EDUSP, 1969. (Coleção Brasiliana, n. 333).

JACKSON, Peter. Medieval cristendom's encounter with the alien. Historical Research, Keele, v. 74, n. 1.986, p. 347-369. 2001.

JARNOUX, Philippe. La France équinoxiale: les dernières velléités de colonisation française au Brésil. Annales de Bretagne et des Pays d'Ouest, Anjou, v. 98, n. 3, p. 273-296. 1991.

MACEDO, José Rivair. Escrita e conversão na África central do século XVII: o catecismo kikongo de 1624. História Revista (UFG), Goiânia, v. 18-1, p. 69-90. 2013a.

. Jagas, canibalismo e guerra preta: os Mbangalas, entre o mito europeu e as realidades da África central no Século XVII. História (UNESP), São Paulo, v. 32, n. 1, p. 53-78. 2013b.

MAESTRI, Mário. O Brasil francês: a colonização revisada. Revista Urutágua, Maringá, n. 14. p. 1-2, 2008.

. Os senhores do litoral: conquista portuguesa e agonia tupinambá no litoral brasílico - século XVI. 3. ed. Porto Alegre: EDUFRGS, 2013. p. 161-167.

MARQUES, João Francisco. Frei Cristovão de Lisboa, missionário no Maranhão e Grão-Pará e a defesa dos índios brasileiros. In: AZEVEDO, Francisca L. Nogueira de; MONTEIRO, John Manuel (Org.). Confronto de culturas: conquista, resistência, transformação. São Paulo: EDUSP; Expressão e Cultura, 1997. p. 229-274.

MÉTRAUX, Alfred. A religião dos tupinambás e suas relações com as demais tribos tupi-guaranis. São Paulo: Livraria Editora Nacional, 1979. (Coleção Brasiliana).

MELATTI, Julio Cesar. Índios do Brasil. São Paulo: EDUSP, 2007.

MILLER, Joseph C. Poder politico e parentesco: os antigos estados mbundu em Angola. Luanda: Arquivo Histórico Nacional, 1995.

NSONDÉ, Jean. Christianisme et religion traditionelle em pays koongo aux XVII-XVIII 
siècles. Cahiers d'Études Africaines, Paris, v. 32, n. 128, p. 705-711. 1992.

PALAZZO, Carmen Lícia. Entre mitos, utopia e razão: os olhares franceses sobre o Brasil (séculos XVI a XVIII). Porto Alegre: EdiPUCRS, 2002.

PARREIRA, A. Economia e sociedade em Angola na época da Rainha Jinga (século XVII). Lisboa: Estampa, 1990.

PINTO, Paulo J. S. Em torno de um problema da identidade. Os jagas na história do Congo e Angola. Mare Liberum (UNL), Lisboa, n. 18-19, p. 193-243. 1999-2000.

RANDLESS, W. G. L. La fondation de la mission des capucins au Royaume du Congo (1648) (Jean-François de Roma, O.F.M.). Annales E.S.C., Paris, v. 23, n. 1, p. 225. 1968.

RICARD, Robert. Misiones Capuchinas en Africa. Bulletin Hispanique, Bordeaux, v. 60-4, p. 557-559. 1958.

ROUX, Jean-Paul. Le sang: mythes, symboles et réalités. Paris: Fayard, 1988.

SILVEIRA, Ildefonso. Crônicas de viagem: franciscanos no Extremo Oriente antes de Marco Polo (1245-1330). Porto Alegre: EDIPUCRS; Bragança Paulista: EDUSF, 2005.

SWEET, James. Recriar a África: cultura, religião e parentesco no mundo afro-português (14411770). Lisboa: Edições 70, 2007. p. 127-140.

THORTON, John. The kingdom of Kongo, ca. 1390-1678. The development of an african social formation. Cahiers d'Études Africaines, Paris, v. 22, n. 87-88, p. 325-342. 1982.

Cannibals, witches, and slave traders in the Atlantic world. The William and Mary Quarterly, Williamsburg, Virginia, v. 60, n. 2, p. 273-294. 2003.

A África e os africanos na formação do mundo atlântico. Rio de Janeiro: Campus, 2004.
. Afro-christian syncretism in the kingdom of Kongo. Journal of African History, Cambridge, v. 54-1, p. 53-77. 2013.

VANSINA, Jan. Les anciens royaumes de la savane: les états des savanes méridionales de l'Afrique centrale des origines à l'occupation coloniale. Léopoldville (Congo): Institut de Recherches Economiques et Sociales, 1965. 